\title{
Parametric Investigation of Heterogeneous Unit Cell Improved by PVDs using FEM
}

\author{
Mohammad reza Motahari \\ Dept. of Civil Engineering, Faculty of Engineering, Arak University, Arak, Iran
}

Received 5 April 2018; Accepted 10 April 2019

\begin{abstract}
Constructing the foundations on saturated soft soils is more likely to be affected by soft clay subsidence. Therefore, in order to increase the consolidation rate in such soils, prefabricated vertical drains are applied to accelerate the soil consolidation and shorten the drainage path. In current research, in order to investigate the layering effect on vertical drains' performance, a parametric study has been conducted on Heterogeneous Unit Cell (HUC) improved with PVDs using Plaxis 2D. For instance, numerical results show that, by decreasing the drains distance from $4.5 \mathrm{~m}$ to $1.5 \mathrm{~m}$ the consolidation degree increased from $25 \%$ to $73 \%$ for the improved HUC in 140 days.
\end{abstract}

Keywords: Soil improvement, Prefabricated vertical drain, Heterogeneous unit cell, Plaxis 2D, Radial consolidation.

\section{Introduction}

One of the highly applicable and economical methods to increase the shear strength of saturated fine-grained soils is the soil improvement using the preloading method which was developed before 1930s. It involves such advantages as simplicity of execution, control and measurement of subsidence, and water pore pressure through instrumentation and investigation of performance and behavior concerning the method. Also, the mentioned method along with PVDs can be implemented in two forms of embankment and vacuum in order to enhance the consolidation rate. Since soft clay needs much time for the consolidation due to low permeability, the installation of PVDs leads to the shortened drainage path and increased consolidation rate; it in turn increases the soil shear strength. Nowadays, few researches have been conducted in this regard to improve the soft soils. Moran (1925) suggested sandy drains technology to improve ground in deep soft deposits [1]. In Sweden, Kjellman (1952) developed the use of stripped PVDs so that each drain consisted of a cardboard core and a filter cover. Later, filter cover was substituted by the unwoven geotextiles. Nowadays, PVDs are widely used for the soil improvement [2]. Contrary to the progress made in realizing the behaviour of embankments on soft ground, the optimal design of such embankments is still difficult and complex. This is especially true, when staged construction, accompanied by pre-fabricated vertical drains in the subsoil, is involved and may justify the use of advanced analytical methods such as Finite Element Method (FEM). The benefits of FEM include its comprehensive ability to model deformations as well as to predict collapse. Providing the consolidation of the soil is suitably modelled the generally advantageous coupling of strength and stiffness with drainage can be properly taken into account. To incorporate the effect of the drains, some way of matching their effect under

*E-mail address: M-motahari@araku.ac.ir

ISSN: $1791-2377$ @ 2019 School of Science, IHU. All rights reserved.

doi:10.25103/jestr.124.22 axisymmetric and plane strain conditions must be found. One of the several possible methodologies was devised by Hird et al. (1992) and permits the average degree of consolidation at all times and at all depths in the soil to be matched, even when there is a significant disturbed and a finite drain permeability [3]. Indraratna et al. (2003) conducted analytical and numerical studies on clay consolidation and found that the decreased soil saturation degree surrounding the vertical drain at the time of installation could reduce the excess pore pressure dissipation rate in first consolidation stage. Also, they reported that determining the soil parameters near the drain might be easier than the inside and outside the area surrounding the drain [4]. Attya et al. (2007) investigated the effectiveness and impact of vertical drains on excess pore pressure dissipation resulting from the cyclic loads. Laboratory behavior of soft soil and PVD under the condition of circular loading with high frequency and the results of a numerical analysis using finite element Plaxis software were compared and concluded that during the circular loading, the existence of PVDs reduced the production rate of excess pore pressure [5]. Indraratna et al. (2008) modelled the consolidation with the vertical drain under a circular embankment numerical and theoretical. Matching onedimensional consolidation degree of unit cell, a value was given for soil permeability coefficient and the analytical solution of radial drainage conjugation equation was developed on cylinder drain walls [6]. Yildiz (2009) confirmed the conformity of two- and three-dimensional plane strain models in relation to vertical drains system [7]. Arul rajah and Bo (2010) in a project of land reclamation in the east of Changi, Singapore modeled the marine clay behavior under the excess load with and without PVDs using finite element Plaxis software and found that the results in terms of symmetric unit cell and scale analyses of all the PVDs were in agreement with those achieved by the precise instrumentation [8]. Bergado et al. (2014) comparing ordinary PVDs and vacuum ones suggested that vacuum PVDs increased the subsidence rate 6-7 times than the ordinary ones with less disturbance in the soil surrounding the drain. Using 
these drains could lead to less disturbance in the surrounding soil [9]. Chen et al. (2016) investigate the performance of these drains in soft clay as a case study in China by the means of precise instrumentation and numerical modeling results in order to study the effective depth of PVDs. Parametric studies results indicated that the increased drain depth with regard to the values given by numerical modelling and instrumentation caused the increased project costs without increasing the soil consolidation degree [10]. In current paper, radial consolidation theory of homogeneous unit cell treated with PVD has been first presented as a theory. Afterwards, to recognize the effective factors in PVD design process, a parametric study on PVD design variables such as installation distance, equivalent diameter, discharge capacity and length of (two layered) heterogeneous unit cell has been conducted using Plaxis 2D software.

\section{Radial Consolidation Theory}

Carillo (1942) developed the following equation for combining the radial and vertical drains effects:

$$
\mathrm{U}=1-\left(1-\mathrm{U}_{\mathrm{V}}\right)\left(1-\mathrm{U}_{\mathrm{h}}\right)
$$

Where, $\mathrm{U}$ is the total consolidation degree. $\mathrm{U}_{\mathrm{v}}$ and $\mathrm{U}_{\mathrm{h}}$ are vertical and radial consolidation degrees which can be computed by the Eq. 2 and Eq.3, respectively [11].

$$
\begin{aligned}
& \mathrm{U}_{\mathrm{v}}=\frac{2 \sqrt{\mathrm{T}_{\mathrm{v}} / \pi}}{\left(1+\left(4 \mathrm{~T}_{\mathrm{v}} / \pi\right)^{2.8}\right)^{0.179}}, \quad \mathrm{~T}_{\mathrm{v}}=\mathrm{c}_{\mathrm{v}} \mathrm{t} / \mathrm{H}^{2} \\
& \mathrm{U}_{\mathrm{h}}=1-\exp \left(\frac{-8 \mathrm{~T}_{\mathrm{h}}}{\mathrm{F}(\mathrm{n})}\right), \quad \mathrm{T}_{\mathrm{h}}=\mathrm{c}_{\mathrm{h}} \mathrm{t} / \mathrm{d}_{\mathrm{e}}{ }^{2}
\end{aligned}
$$

$\mathrm{T}_{\mathrm{v}}$ is the timeless factor for vertical drainage, cv is the vertical consolidation coefficient, $\mathrm{H}$ is the maximum vertical drainage path length, $\mathrm{C}_{\mathrm{h}}$ is the horizontal consolidation coefficient, $T_{h}$ is the timeless factor for radial drainage and $d_{e}$ is the equivalent circle diameter in relation to drain impact given as 1.05 and 1.13 times more than drains distance (s) for square pattern, as shown in Fig. 1 [2]. F(n) is a parameter involving the intervals, equivalent diameter, drain outlet discharge capacity and intact soil area surrounding the drain which is computed by the Eq. 4 as follows:

$$
\mathrm{F}(\mathrm{n})=\ln (\mathrm{n})-\frac{3}{4}, \quad \mathrm{n}=\frac{\mathrm{d}_{\mathrm{e}}}{\mathrm{d}_{\mathrm{w}}}
$$

In above equation, $\mathrm{n}$ is the drain well diameter, de is the equivalent circle diameter related to drain impact and $d_{w}$ is the drain well diameter; the following equation is used to estimate the drain well diameter in terms of stripped drains , as shown in Fig.2.

$$
\mathrm{d}_{\mathrm{w}}=2(\mathrm{a}+\mathrm{b}) / \pi
$$

In above equation, $\mathrm{a}$ and $\mathrm{b}$ are the width and diameter of PVD, respectively. FHWA suggests the reduction of strip vertical drain equivalent diameter as $a / b<50$ according to the Eq. $6[2]$.

$$
\mathrm{d}_{\mathrm{w}}=(\mathrm{a}+\mathrm{b}) / 2
$$

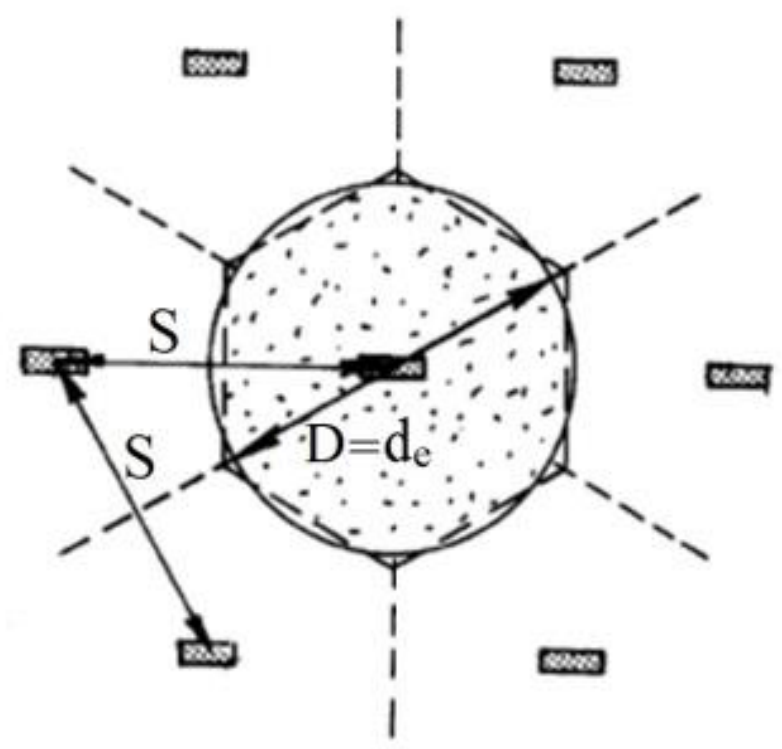

Fig 1. Arrangement of drain wells

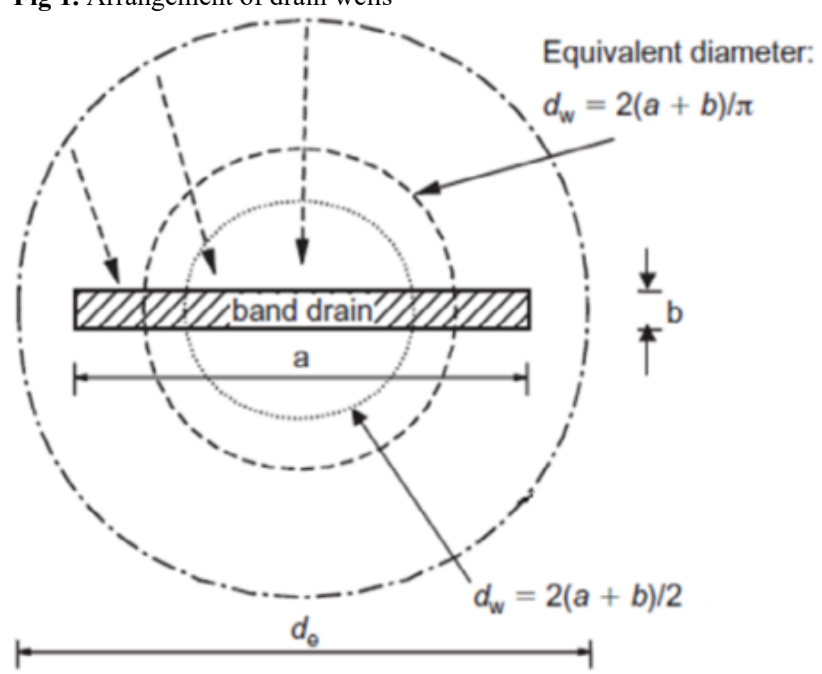

Fig 2. Equivalent diameter of strip drain

Effects of soil disturbance due to the drain installation and good PVD resistance are more likely to be simulated with vertical permeability, $K_{v e}$, as follows:

$$
\begin{aligned}
& \mathrm{k}_{\mathrm{ve}}=\left(1+\frac{2.5 \mathrm{~L}_{\mathrm{d}}^{2}}{\mu \mathrm{d}_{\mathrm{e}}{ }^{2}} \frac{\mathrm{k}_{\mathrm{h}}}{\mathrm{k}_{\mathrm{v}}}\right) \mathrm{k}_{\mathrm{v}} \\
& \mu=\ln \frac{\mathrm{n}}{\mathrm{s}}+\frac{\mathrm{k}_{\mathrm{h}}}{\mathrm{k}_{\mathrm{s}}} \operatorname{lns}-\frac{3}{4}+\pi \frac{2 \mathrm{~L}_{\mathrm{d}}{ }^{2} \mathrm{k}_{\mathrm{h}}}{3 \mathrm{q}_{\mathrm{w}}}
\end{aligned}
$$

where $\mathrm{d}_{\mathrm{e}}\left(=2 \mathrm{r}_{\mathrm{e}}\right)$ is drain impact area diameter, $\mathrm{n}\left(=\mathrm{d}_{\mathrm{e}} / \mathrm{d}_{\mathrm{w}}\right)$ is impact factor or distance coefficient, $\mathrm{s}\left(=\mathrm{d}_{\mathrm{s}} / \mathrm{d}_{\mathrm{w}}\right)$ is disturbance coefficient, $\mathrm{L}_{\mathrm{d}}$ is drain length and $\mathrm{q}_{\mathrm{w}}$ is PVD discharge capacity interpreted as good vertical drain resistance. It is noteworthy that good vertical drain resistance can postpone the water flow in the drainage canal and reduce soft clay layer consolidation value. Good resistance factor is defined based on the Eq. 9.

$$
\mathrm{R}=\pi \mathrm{k}_{\mathrm{w}} \mathrm{r}_{\mathrm{w}}^{2} / \mathrm{k}_{\mathrm{h}} \mathrm{L}_{\mathrm{d}}{ }^{2}
$$


In numerical analyses, good PVD resistance is modelled by specific length permeability $\mathrm{k}_{\mathrm{w}}$. Investigating the vertical drains area performance in soft clay deposit has indicated that good resistance can be ignored when $\mathrm{R}>5$ [12].

\section{Numerical Modeling}

To determine the accuracy of computations, the results of numerical model using the commercial finite-element software Plaxis 2D is first compared to the results achieved by the case study. Then, if they are matched, the software outputs may be considered as valid data in our present parametric study.

\subsection{Case study}

Kharg petrochemical complex is located in Kharg Island. This island, has peered out of the water as coral island in the northwest part of the Persian Gulf. Kharg Island situated 57 kilometres northwest of Boushehr, is considered to be one of the coastal suburbs of Boushehr province. Petrochemical site topography is relatively flat and shallow with average height of +0.5 . To establish a horizontal platform, the average layer thickness given as $4 \mathrm{~m}$ executed in the desired area involves $1 \mathrm{~m}$ sand blanket, $2 \mathrm{~m}$ embankment, and $1 \mathrm{~m}$ excess embankment in order to keep the site higher than settlement plate and reach final height estimated as $+2.5 \mathrm{~m}$ above sea level. According to soil laboratory results, the area is classified into 3 distinct layers. Upper layer with the thickness of $6 \mathrm{~m}$ is very soft and next, there is a $6 \mathrm{~m}$ layer of soft clay enclosed by sand. To accelerate the consolidation process, PVDs are installed with $4 \mathrm{~m}$ intervals in a triangular form at the depth of $12 \mathrm{~m}$. A sand blanket with $1 \mathrm{~m}$ thickness is executed as workshop area. PVD and site plan have been demonstrated in Fig. 3 (a,b) [14].

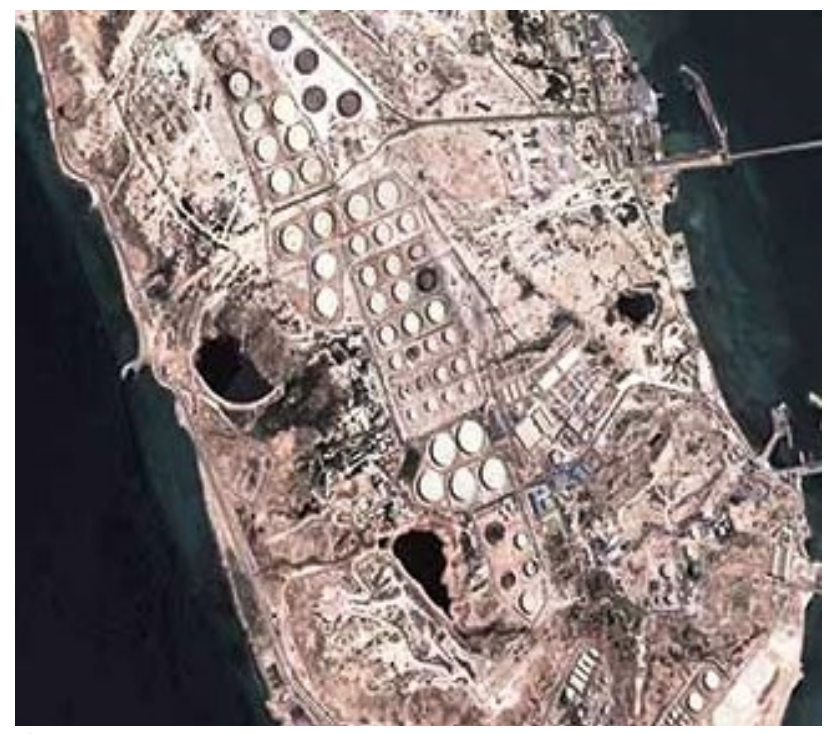

a) Petrochemical compl

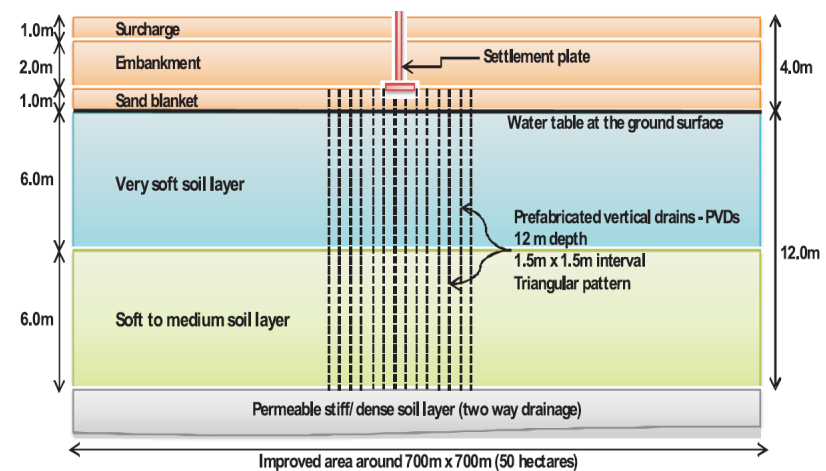

b) PVDs arrangement and location

Fig. 3. PVDs and site plan

\subsection{Numerical analysis of heterogeneous unit cell improved by PVD}

Heterogeneous unit cell improved with PVD corresponding Kharg petrochemical complex conditions consisting of two soil layers was analysed with regard to symmetric circumstances using Plaxis 2D software according to Tabs. 1 $\& 2$. In the modelling of vertical and horizontal DOF, end of the model has been fixed but the borderlines are free for vertical movement. Also, borderlines were closed for drainage and only top and bottom borders were opened for modelling the two-way drainage. Axisymmetric conditions were chosen to simulate a heterogeneous unit cell condition with a single drain at the centre of the filled area. The total number of 15-noded triangular elements in this model is 981 . The soil and the embankment were modelled using the hardening soil model, the advanced soil model in Plaxis 2D for simulating both soft and stiff soils. PVDs were installed at the depth of $12 \mathrm{~m}$. Geometric model and finite element meshing have been shown concerning heterogeneous unit cell in Fig. 4. Computation phases have been summarized for simulating the embankment construction stages in Tab. 3 [14].

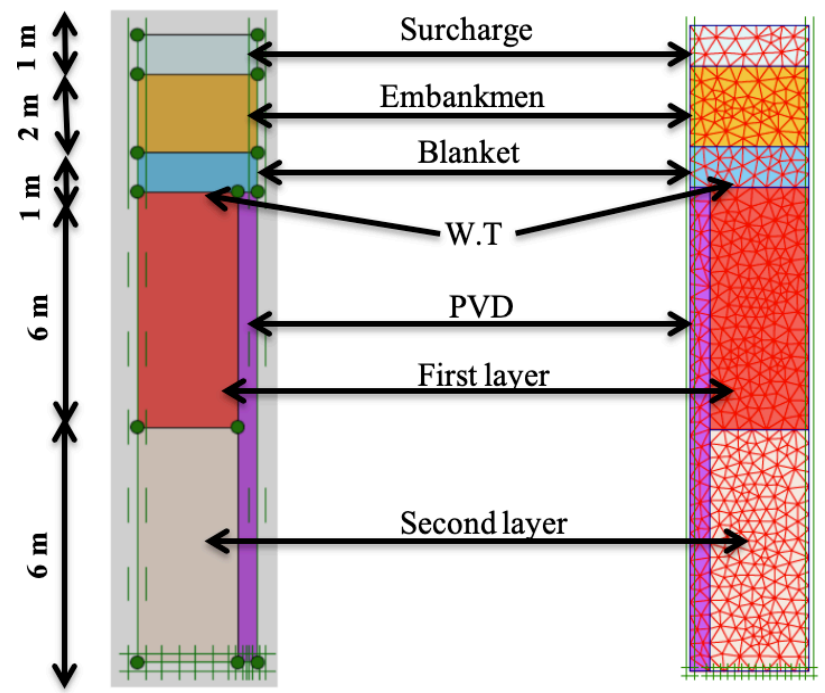

Fig.4. Geometric model and finite element mesh for HUC improved by PVD

Table 1. Soil and embankment properties for heterogeneous unit cell

\begin{tabular}{c|c|c|c|c|c|c}
\hline $\begin{array}{c}\text { Hardening soil } \\
\text { model } \\
\text { parameters }\end{array}$ & $\begin{array}{c}\text { Drain } \\
\text { condition }\end{array}$ & $\begin{array}{c}\text { Thickness } \\
\mathbf{( m )}\end{array}$ & $\begin{array}{c}\gamma_{\text {unat }} / \gamma_{\text {sat }} \\
\mathbf{k N} / \mathbf{m}^{\mathbf{3}}\end{array}$ & $\begin{array}{c}\boldsymbol{E}_{50}^{\text {ref }}=\boldsymbol{E}_{\text {oed }}^{\text {ref }} \\
\mathbf{k N} / \mathbf{m}^{\mathbf{2}}\end{array}$ & $\begin{array}{c}\boldsymbol{E}_{\text {ur }}^{\text {ref }} \\
\mathbf{k N} / \mathbf{m}^{\mathbf{2}}\end{array}$ & $\begin{array}{c}\text { Power } \\
(\mathbf{m})\end{array}$ \\
\hline $\begin{array}{c}\text { First soil layer } \\
\text { Second soil } \\
\text { layer }\end{array}$ & $\begin{array}{c}\text { No drainage } \\
\text { No drainage }\end{array}$ & 6 & 15.16 & 1000 & 3000 & 0.9 \\
\end{tabular}




\begin{tabular}{|c|c|c|c|c|c|c|c|}
\hline Embankment & Drainage & 4 & \multicolumn{2}{|c|}{18.20} & 000 & 60000 & 0.5 \\
\hline $\begin{array}{c}\text { Hardening soil } \\
\text { model } \\
\text { parameters }\end{array}$ & $\begin{array}{c}\boldsymbol{c}_{r e f}^{\prime} \\
\mathbf{k N} / \mathbf{m}^{2}\end{array}$ & $\varphi^{\circ}$ & $\boldsymbol{U}_{r e f}^{\prime}$ & $\begin{array}{c}\rho_{\text {ref }} \\
\mathbf{k N} / \mathbf{m}^{3}\end{array}$ & $\boldsymbol{K}_{0}^{n c}$ & $R_{f}$ & $K_{h}=K_{v}(\mathbf{m} / \mathbf{s})$ \\
\hline First soil layer & 12 & 24 & 0.2 & 100 & 0.59 & 0.9 & $1.9 \times 10^{-9}$ \\
\hline Second soil layer & 1 & 28 & 0.2 & 100 & 0.53 & 0.9 & $5 \times 10^{-9}$ \\
\hline Embankment & 10 & 30 & 0.2 & 100 & 0.5 & 0.9 & $1 \times 10^{-7}$ \\
\hline
\end{tabular}

Table 2. Drain properties

\begin{tabular}{c|c|c|c|c|c|c|c}
\hline $\begin{array}{c}\mathbf{q}_{\mathbf{w}} \\
\left.\left(\mathbf{m}^{3} / \mathbf{y e a r}\right)\right)\end{array}$ & $\mathbf{S}(\mathbf{m})$ & $\begin{array}{c}\mathbf{d}_{\mathbf{s}} \\
(\mathbf{m m})\end{array}$ & $\begin{array}{c}\mathbf{d}_{\mathbf{e}} \\
(\mathbf{m})\end{array}$ & $\mathbf{d}_{\mathbf{w}}(\mathbf{m m})$ & $\mathbf{S}$ & $\mathbf{n}$ & $\mathbf{L}(\mathbf{m})$ \\
\hline 100 & 1.5 & 360 & 1.575 & 66 & 5.45 & 23.86 & 12 \\
\hline
\end{tabular}

Table 3. Embankment construction stages

\begin{tabular}{|c|c|c|c|}
\hline No & $\begin{array}{c}\text { Stage of } \\
\text { Construction }\end{array}$ & Date & Days \\
\hline 1 & $\begin{array}{l}\text { Site clearing and } \\
\text { preparation }\end{array}$ & $\begin{array}{l}16 \text { November- } 25 \\
\text { November } 2007\end{array}$ & 10 \\
\hline 2 & $\begin{array}{c}0.5 \mathrm{~m} \text { Sand } \\
\text { Blanket }(+0.5 \mathrm{~m})\end{array}$ & $\begin{array}{l}26 \text { November-27 } \\
\text { November } 2007\end{array}$ & 2 \\
\hline 3 & Consolidation & $\begin{array}{c}28 \text { November-29 } \\
\text { November2007 }\end{array}$ & 2 \\
\hline 4 & $\begin{array}{c}0.5 \mathrm{~m} \text { Sand } \\
\text { Blanket }(+1.0 \mathrm{~m})\end{array}$ & 30 November 2007 & 1 \\
\hline 5 & Consolidation & $\begin{array}{l}01 \text { December-06 } \\
\text { December }\end{array}$ & 5 \\
\hline 6 & $\begin{array}{l}\text { PVD+ Smear } \\
\text { Installation }\end{array}$ & $\begin{array}{c}06 \text { December-08 } \\
\text { December } 2007\end{array}$ & 3 \\
\hline 7 & Consolidation & $\begin{array}{c}09 \text { December-10 } \\
\text { December } 2007\end{array}$ & 2 \\
\hline 8 & $\begin{array}{c}0.15 \mathrm{~m} \\
\text { Embankment } \\
(+1.15 \mathrm{~m})\end{array}$ & 11 December 2007 & 1 \\
\hline 9 & $\begin{array}{c}0.3 \mathrm{~m} \text { Embankment } \\
(+1.45 \mathrm{~m}) \\
0.55 \mathrm{~m}\end{array}$ & 12 December 2007 & 1 \\
\hline 10 & $\begin{array}{c}\text { Embankment } \\
(+2.0 \mathrm{~m})\end{array}$ & 13 December 2007 & 1 \\
\hline 11 & Consolidation & $\begin{array}{l}14 \text { December-16 } \\
\text { December2007 }\end{array}$ & 3 \\
\hline 12 & $\begin{array}{c}0.25 \mathrm{~m} \\
\text { Embankment } \\
(+2.25 \mathrm{~m})\end{array}$ & 17 December 2007 & 1 \\
\hline 13 & $\begin{array}{l}\text { Consolidation } \\
0.25 \mathrm{~m}\end{array}$ & 18 December 2007 & 1 \\
\hline 14 & $\begin{array}{l}\text { Embankment } \\
\qquad(+2.5 \mathrm{~m})\end{array}$ & 19 December 2007 & 1 \\
\hline 15 & Consolidation & $\begin{array}{c}20 \text { December-27 } \\
\text { December2007 }\end{array}$ & 8 \\
\hline 16 & $\begin{array}{c}0.5 \mathrm{~m} \text { Embankment } \\
(+3.0 \mathrm{~m})\end{array}$ & 28 December 2007 & 1 \\
\hline 17 & Consolidation & $\begin{array}{c}29 \text { December-04 } \\
\text { January } 2008\end{array}$ & 7 \\
\hline 18 & $\begin{array}{c}1.0 \mathrm{~m} \\
\text { Surcharge }(+4.0 \mathrm{~m})\end{array}$ & 05 January 2008 & 1 \\
\hline
\end{tabular}

\subsection{Results verification}

To confirm the numerical modelling using Plaxis 2D, total degree of consolidation has been compared to the results of theory and instrumentation. According to Fig. 5, appropriate conformity and convergence have been observed among the results reported by numerical analysis, theory and instrumentation at the interval of 350 days. Therefore, software outputs can be applied as valid data in future parametric studies.

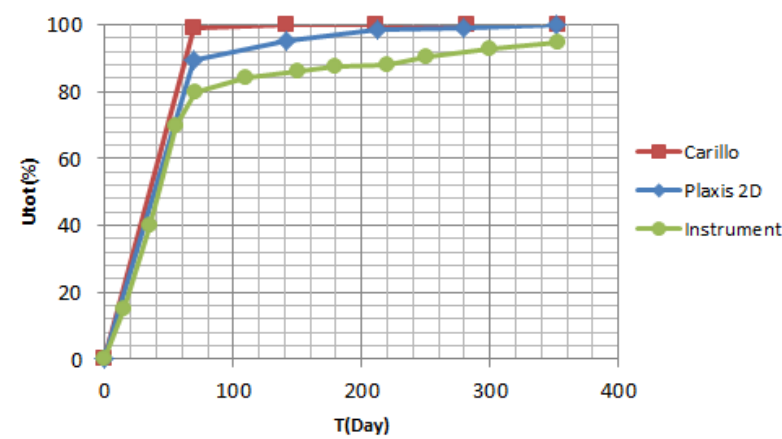

Fig. 5. Comparison of consolidation degree; theory, numerical analysis and FEM

\section{Parametric Study}

By numerical modeling of heterogeneous unit cell improved with PVD, a series of parametric studies have been conducted on PVDs design parameters such as installation interval, discharge capacity, length and diameter. After that, variation of consolidation rate, subsidence and excess pore pressure dissipation were checked. Above-mentioned variations have been summarized in Tab. 4.

Table 4. Variation of PVDs installation interval, diameter and discharge capacity for HUC

\begin{tabular}{|c|c|c|c|c|c|}
\hline \multicolumn{6}{|c|}{ PVDs installation distance variation } \\
\hline $\mathbf{S}(\mathbf{m})$ & $\begin{array}{c}d_{e} \\
(m)\end{array}$ & $\begin{array}{c}d_{w} \\
(\mathrm{~mm} \\
)\end{array}$ & $\begin{array}{r}q_{w}(m 3 / y e a \\
r)\end{array}$ & $\begin{array}{c}k_{\mathrm{e}} \\
\text { soil1 }(\mathrm{mm} / \mathrm{da} \\
\mathbf{y}) \\
\end{array}$ & $\begin{array}{c}k_{\mathrm{e}} \\
\text { soil2 }(\mathrm{mm} / \mathrm{da} \\
\mathbf{y}) \\
\end{array}$ \\
\hline 1.5 & $\begin{array}{c}1.57 \\
5\end{array}$ & 66 & 100 & 0.1594 & 0.4131 \\
\hline 3 & 3.15 & 66 & 100 & 0.4707 & 0.1227 \\
\hline 4.5 & $\begin{array}{c}4.72 \\
5 \\
\end{array}$ & 66 & 100 & 0.2899 & 0.5783 \\
\hline \multicolumn{6}{|c|}{ PVDs diameter variation } \\
\hline $\mathbf{d}_{\mathrm{w}}(\mathbf{m m})$ & $\begin{array}{c}\text { S(m } \\
)\end{array}$ & $\begin{array}{c}d_{e} \\
(m)\end{array}$ & $\begin{array}{r}q_{w}(m 3 / y e a \\
r)\end{array}$ & $\begin{array}{c}k_{\mathrm{e}} \\
\text { soil1 }(\mathrm{mm} / \mathrm{da} \\
\mathbf{y}) \\
\end{array}$ & $\begin{array}{c}k_{\mathrm{e}} \\
\text { soil2 }(\mathrm{mm} / \mathrm{da} \\
\mathbf{y}) \\
\end{array}$ \\
\hline 66 & 1.5 & $\begin{array}{c}1.57 \\
5\end{array}$ & 100 & 0.1594 & 0.4131 \\
\hline 132 & 1.5 & $\begin{array}{c}1.57 \\
5 \\
\end{array}$ & 100 & 0.2308 & 0.5929 \\
\hline \multicolumn{6}{|c|}{ PVDs discharge capacity variation } \\
\hline $\begin{array}{r}q w(m 3 / y e a \\
r)\end{array}$ & $\begin{array}{c}\text { S(m } \\
)\end{array}$ & $\begin{array}{c}d_{\mathrm{e}} \\
(\mathrm{m})\end{array}$ & $d_{w}(\mathbf{m m})$ & $\begin{array}{c}k_{e} \\
\operatorname{soil1}(\mathrm{mm} / \mathrm{da} \\
y) \\
\end{array}$ & $\begin{array}{c}k_{e} \\
\text { soil2 }(\mathrm{mm} / \mathrm{da} \\
\mathrm{y}) \\
\end{array}$ \\
\hline 10 & 1.5 & $\begin{array}{c}1.57 \\
5\end{array}$ & 66 & 0.1467 & 0.3385 \\
\hline 100 & 1.5 & $\begin{array}{c}1.57 \\
5\end{array}$ & 66 & 0.1594 & 0.4131 \\
\hline 1000 & 1.5 & $\begin{array}{c}1.57 \\
5 \\
\end{array}$ & 66 & 0.161 & 0.423 \\
\hline
\end{tabular}

\subsection{Distance variation}

Regarding the fixed discharge capacity and diameter based on Tab. 4, average consolidation degree, subsidence and excess pore pressure dissipation of unit cell improved with PVD have been demonstrated in Figs. 6 to 8 for the intervals of 1.5, 3 and $4.5 \mathrm{~m}$. 


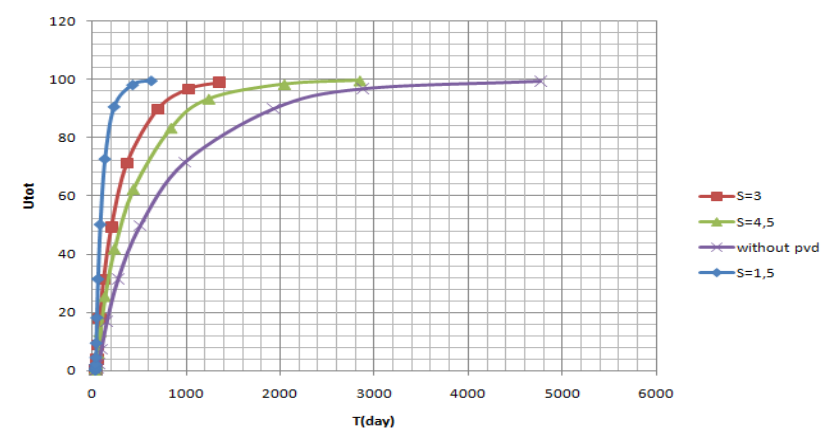

Fig. 6. HUC consolidation rate for intervals of $1.5,3$ and $5 \mathrm{~m}$
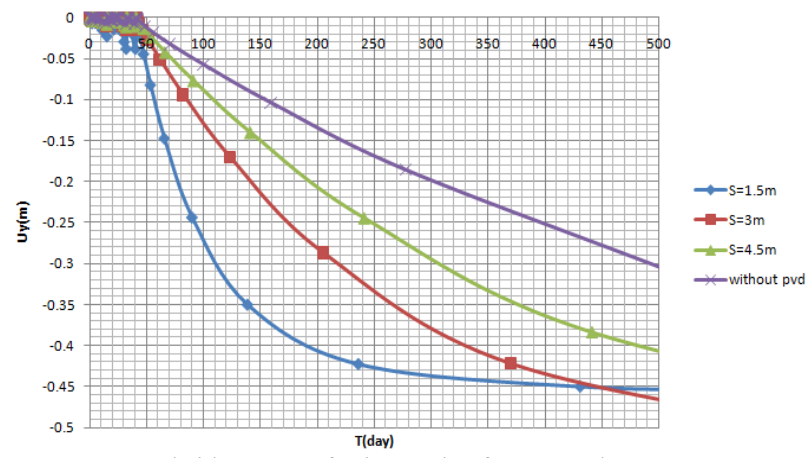

Fig. 7. HUC subsidence rate for intervals of $1.5,3$ and $5 \mathrm{~m}$

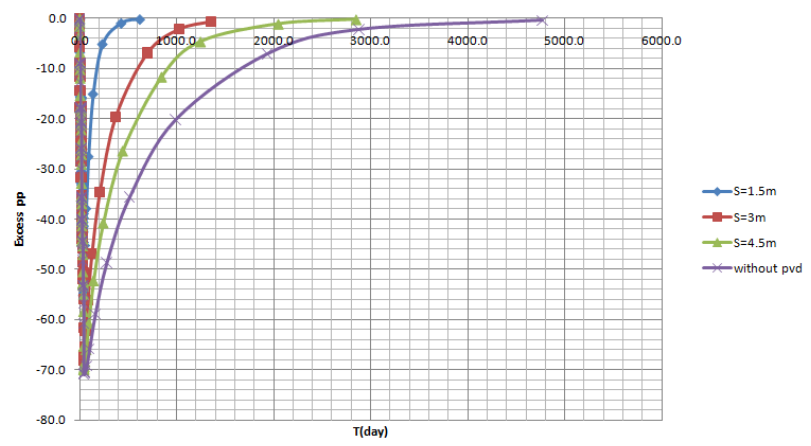

Fig. 8. HUC excess pore pressure dissipation rate for intervals of $1.5,3$ and $5 \mathrm{~m}$

According to the above figures, the reduced drains intervals increased the unit cell subsidence, excess pore pressure dissipation and consolidation value. For example, the decrease of PVDs intervals from 4.5 to $1.5 \mathrm{~m}$ led to the increased value of $\mathrm{U}(\%)$ from $25 \%$ to $73 \%$ for 140 days. According to Fig. 16, without PVD, 2800 days were reduced to 1400 and then 600 days at the intervals of $1.5,3$ and $4.5 \mathrm{~m}$. As shown in Fig. 7, the decreased drains intervals from 4.5 to $1.5 \mathrm{~m}$ enhanced the subsidence value from 14 to $35 \mathrm{~cm}$ in 140 days.

\subsection{Diameter variation}

Assuming the PVD discharge capacity and installation distance were fixed, Tab. 4 has presented the curve of average consolidation degree, subsidence and excess pore pressure dissipation of unit cell improved with PVD for diameters of 66 and $132 \mathrm{~mm}$.

As shown in Figs 9 to 11, it can be clearly observed that the increase in PVD diameter will increase the consolidation and subsidence value of unit cell improved with PVD and dissipate the excess pore pressure. For example, the increase in PVD diameter from 66 to $132 \mathrm{~mm}$ enhances the value of $\mathrm{U}(\%)$ from 78.11 to 81.75 and as well, the subsidence value is increased from 10.7 to $14.3 \mathrm{~cm}$ at the same time.

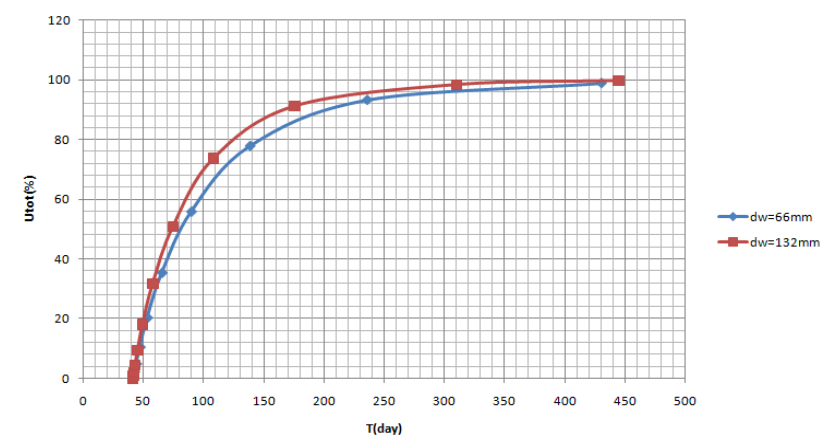

Fig. 9. HUC consolidation rate for diameters of 66 and $132 \mathrm{~mm}$

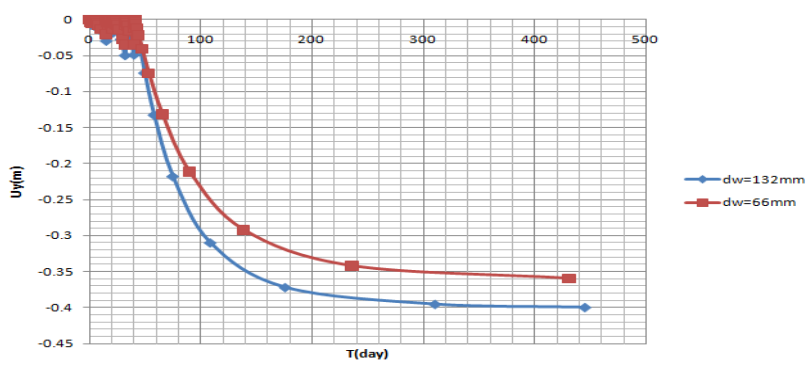

Fig. 10. HUC subsidence rate for diameters of 66 and $132 \mathrm{~mm}$

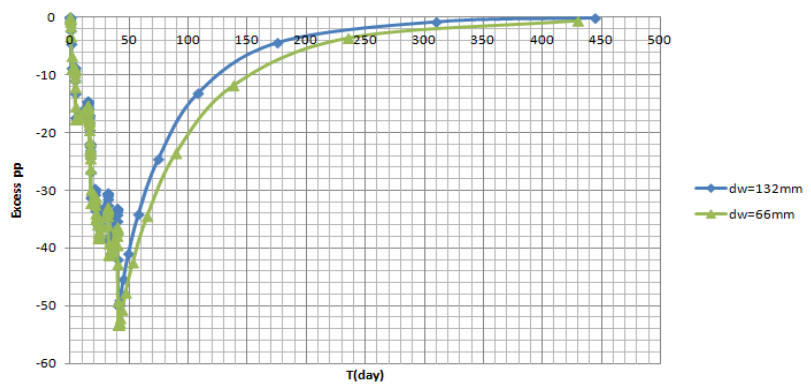

Fig. 11. HUC pore pressure dissipation rate for diameters of 66 and 132 $\mathrm{mm}$

\subsection{Discharge capacity variation}

Considering fixed installation distance and diameter according to Tab. 4, the average consolidation, subsidence and excess pore pressure dissipation values have been presented for the discharge capacities of 10,100 and $1000 \mathrm{~m}^{3}$ $\mathrm{s}^{-1}$ in Figs. 12 to 14.

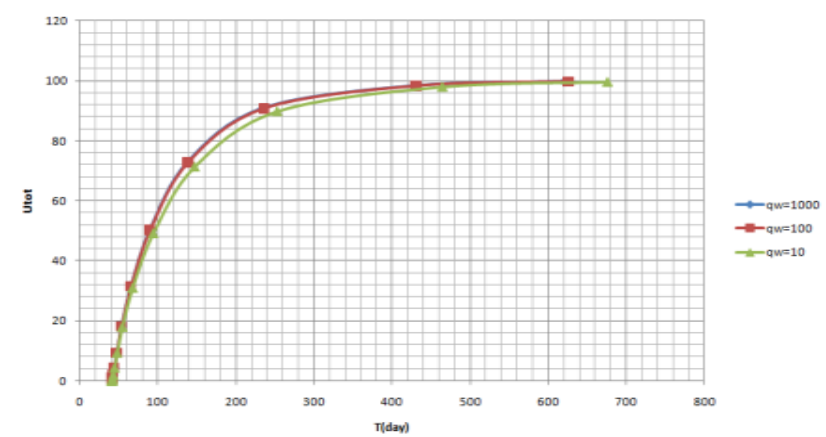

Fig. 12. HUC consolidation rate for discharge capacities of 10, 100 and $100 \mathrm{~m}^{3} \mathrm{~s}^{-1}$

According to above figures, as the discharge capacity increases, the subsidence, consolidation and pore pressure dissipation values increase; though, no considerable impact is observed. For example, as the discharge capacity increases by 100 times (from 10 to $1000 \mathrm{~m}^{3} \mathrm{~s}^{-1}$ ), the $\mathrm{U}(\%)$ value is changed from 68.47 to 73.51 in 140 days. 


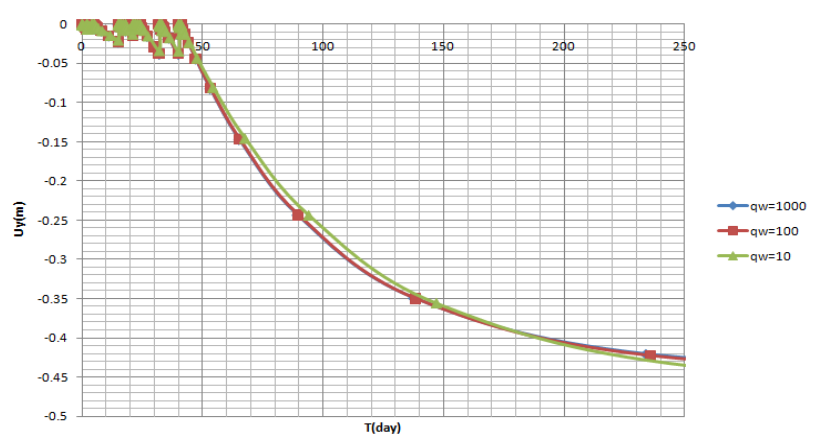

Fig. 13. HUC subsidence rate for discharge capacities of 10,100 and 100 $\mathrm{m}^{3} \mathrm{~s}^{-1}$

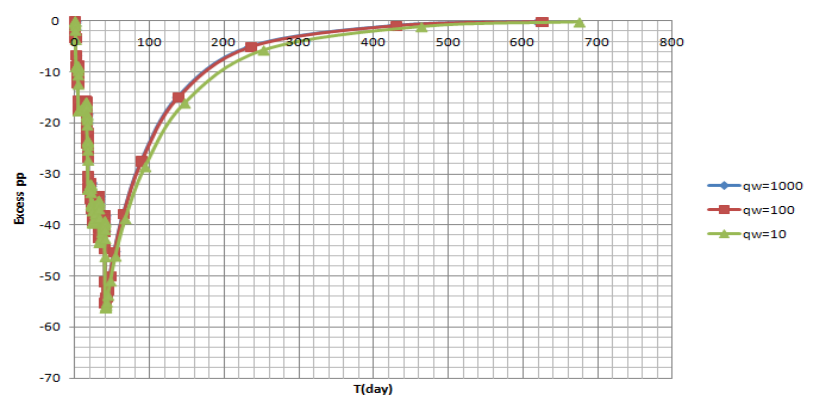

Fig. 14. HUC pore pressure dissipation rate for discharge capacities of 10,100 and $100 \mathrm{~m}^{3} \mathrm{~s}^{-1}$

\section{Summary and Conclusions}

\subsection{Summary}

From literature review that has been studied, the FEM analysis had successfully predicted the behavior of soft clay improved with PVD. It is also confirm in this study that the consolidation settlement predicted by FEM analysis shows reasonable agreement with the field monitoring settlement results for PVD treated soft ground [14]. Ultimate settlement at site was predicted using Carillo analytical method [11]. It was found that ultimate settlement predicted from FEM is lower compared to actual field settlement monitoring result.

\subsection{Conclusions}

In the current study, to understand the consolidation behavior of unit cell improved with PVD, a parametric study has been conducted on heterogeneous unit cell with respect to PVD design variables as installation distance, diameter, discharge capacity and length using Plaxis 2D finite element software. The following results have been achieved:

1. Comparing consolidation, subsidence and pore pressure dissipation values of heterogeneous unit cell improved with PVD and regarding three drain installation intervals $(1.5,3$ and $4.5 \mathrm{~m})$, it can be found that the consolidation time was reduced from 4700 days to 2800, 1400 and 600 days without PVD and changing the drain intervals from 4.5 to $1.5 \mathrm{~m}$, the consolidation value has increased by $48 \%$ for 140 days. As well, by doubling the PVD diameter, the consolidation value is increased by $3.64 \%$.

2. Considering various discharge capacities, total consolidation, subsidence and pore pressure dissipation values in terms of heterogeneous unit cell improved with PVD, as the drain discharge capacity has been increased 100 times, consolidation value increased by $5.04 \%$ and the curves of consolidation, subsidence and pore pressure dissipation values have been matched in terms of various discharge capacities. Also, doubling the drain diameter, total consolidation value relatively increased by $0.45 \%$ in 6 months; it suggests that the PVD diameter effect is not considerable.

3- It should be noted that among effective parameters in consolidation trend of unit cell improved with PVD, at first the installation interval variation and then, drainage length variation have been of the most effects on the increased efficiency followed by the increased PVDs discharge capacity and diameter effects.

Finally, it will be important that future numerical and experimental researches investigate the effect of floating PVDs in a double drainage condition on consolidation degree and pore pressure dissipation rate.

This is an Open Access article distributed under the terms of the Creative Commons Attribution License

\section{References}

[1] Paul, S., Varghese, E., \& Stephen, L. "Prefabricated Vertical Drain", International Journal of Engineering Research and Development, 10, 2014, pp. 50-55.

[2] Federal Highway Administration. "Prefabricated Vertical Drains", Engineering Guidelines Report No. RD: 86/168, 1986.

[3] Hird, C.C., Pyrah, LC., and Russell, D. "Discussion on finite element analysis of the collapse of reinforced embankments on soft ground", Geotechnique, 41, 1991, pp. 627-630.

[4] Indraratna, B., Bamunawita, C., Redana, I., \& McIntosh, G. "Modeling of Prefabricated Vertical Drains in Soft Clay and Evaluation of Their Effectiveness in Practice", Ground Improvement, 7(3), 2003, pp. 127-138.

[5] Attya, A., Indraratna, B., \& Rujikiatkamjorn, C. "Effectiveness of Vertical Drains on Dissipating Excess Pore Pressures induced by Cyclic Loads in Clays", Proceeding of the $16^{\text {th }}$ Southeast Asian Geotechnical Conference, Selangor, Malaysia, 2007.

[6] Indraratna, B., Aljorany, A.N., \& Rujikiatkamjorn, C. "Analytical and Numerical Modeling of Consolidation by Vertical Drain beneath a Circular Embankment", International Journal of Geomechanics, 8(3), 2008, pp. 199-206.
[7] Yildiz, A. "Numerical Modeling of Vertical Drains with Advanced Constitutive Models", Computers and Geotechnics. 36(6), 2009, pp. 1072-1083.

[8] Arul rajah, A., \& Bo, M.W. "Finite Element Modeling of Soft Soil Treated with Prefabricated Vertical Drains", International Journal of Geotechnical Engineering 4, 2010, pp. 165-179.

[9] Bergado, D.T., Voottipruex, P., Lam, L.G., \& Hino, T. "BackAnalyses of Flow Parameters of PVD Improved Soft Bangkok Clay with and without Vacuum Preloading from Settlement Data and Numerical Simulations", Geotextiles and Geomembranes. 42, 2014, pp. 457-467.

[10] Chen J., Shen S., Yin Z. Y., Xu Y. S. "Horpibulsuk S, Evaluation of Effective Depth of PVD Improvement in Soft Clay Deposit: a Field Case Study", Marine Georesources \& Geotechnology, 10(5), 2016, pp. 101-112.

[11] Carillo N. "Simple Two and Three Dimensional Cases in The Theory of Consolidation of soils", Journal of Mathematics and Physics. 21(1), 1942, pp. 1-5.

[12] Chai, J., Bergado, D.T., Long Shen, S. "Modeling Prefabricated Vertical Drain Improved Ground in Plane Strain Analysis", Ground Improvement. 166, 2013, pp. 65-77. 
[13] A. A, Balkema. Plaxis 2D user Manual: Finite element code for soil and rock analyses, Plaxis bv., Netherland, Version 8.2, 1998.
[14] Report on Soil Improvement Project for Kharg Oil Storages. Sahel Consultant Engineering Co, $3^{\text {rd }}$ Edition, (In Persian), 2009. 